\title{
Ways of Transferring the Internal Speech of Characters: Psycholinguistic Projection
}

\section{Спосо6и передавання внутрішнього мовлення персонажів: психолінгвістична проекція}

\author{
Liudmyla Shytyk ${ }^{1}$ \\ Dr. in Philology, \\ Associate Professor
}

\author{
Людмила Шитик ${ }^{1}$ \\ доктор філологічних наук, \\ доцент
}

\author{
E-mail: 1 shytyk@ukr.net \\ https://orcid.org/0000-0001-5941-672X
}

\author{
Аліна Акімова ${ }^{2}$ \\ кандидат філологічних наук, \\ доцент
}

E-mail: a_alina09@ukr.net https://orcid.org/0000-0001-7546-2902

ResearcherID: C-5824-2017

${ }^{1}$ Cherkasy Bohdan Khmelnytskyi

National University, Department

of Ukrainian Linguistics and Applied Linguistics

$\triangle 81$, T. Shevchenko Boul., Cherkasy, Ukraine, 18031

${ }^{2}$ Interregional Academy

of Personnel Management

$\checkmark$ 2, Frometivska Str., Kyiv, Ukraine, 203039
${ }^{1}$ Черкаський національний університет імені Богдана Хмельницького, кафедра українського мовознавства і прикладної лінгвістики $\triangle$ бульвар Т. Шевченка, 81, Черкаси, Україна, 18031

${ }^{2}$ Міжрегіональна Академія управління персоналом

$\checkmark$ вул. Фрометівська, 2, Київ, Україна, 203039

Original manuscript received August 08, 2018

Revised manuscript accepted April 08, 2020 


\section{ABSTRACT}

Objective. The purpose of the article is to provide a comprehensive analysis of the ways of transmitting the characters' internal speech (internal direct speech and non-proper direct speech) in a psycholinguistic projection.

Materials \& Methods. During the research we used general scientific methods (analysis, synthesis, observation, description, classification, definitive analysis), linguistic and psycholinguistic methods (the methods of structural-semantic, component and opposition analysis, the method of dialogical interpretation of the text). Stepan Protsyuk's psychologically biographical trilogy about Ukrainian writers - Vasyl Stefanyk ("The rose of ritual pain»), Arkhyp Teslenko ("Black Apple») and Volodymyr Vynnychenko ("Masks fall slowly») served as material for research.

Results. The multiplicity and multi-sectoral focus of the notion of "internal speech» from the standpoint of psychology, psycholinguistics, philosophy, literary criticism and linguistics are determined. An integrated approach to understanding the essence of internal speech is based on its dialogicality, virtual communicativeness, selfcommunicativeness and interdependence of language and speech. The qualification characteristics of the internal direct speech and non-proper direct speech are outlined, their structural and semantic varieties are described. The internal speech of the characters appears not only for reproduction of the monologic reflections of the character, but also as a form of inner, veiled talk of characters among themselves. With this in mind, two forms of representation of the internal direct speech are singled out: monologic and dialogic. The non-proper direct speech is differentiated into two varieties depending on stylistic reference points and the degree of approaching the direct speech: "literary» ("author's») and "character's» ("personal»). The functionalstylistic potential of ways of transferring the internal speech in the idiostyle of Stepan Protsiuk is revealed.

Conclusions. It is concluded that the ways of transmitting of internal speech (internal direct speech and non-proper direct speech) widely used in the psychologically biographical novels of Stepan Protsiuk provide additional linguistic material for creating of psychological portraits of heroes and contribute to the artistic solution of the tension between the author's speech and hero's speech. Moreover, they help to adjust the interactions in their dialogue, reduce the distance between the narrator and the hero, the hero and the reader.

Key words: internal speech, internal monologue, internal direct speech, non-proper direct speech, another's speech, syncretic ways of transferring another's speech.

\section{Вступ}

Проблема внутрішнього мовлення як складного, різнопланового явища, пов'язаного 3 мовою, мисленням, пізнавальною, чуттєвою та практичною діяльністю людини, 
потребує багатоаспектного дослідження в царинах психології, психолінгвістики, філософії мови, лінгвостилістики, текстології, літературознавства тощо. Дослідження цього феномену потребує міждисциплінарного підходу, що зумовлено неоднозначністю й поліфункційністю способів передавання внутрішнього мовлення як моделей вербалізованого мислення.

Різні способи передавання внутрішнього мовлення в художніх творах забезпечують психологічну характеристику внутрішнього світу персонажа, формують його психологічний портрет і створюють емоційність викладу. Прийом зображення

«очима героя» допомагає наблизити авторський описовий виклад до мови героїв, слугує засобом «досягнення поліфонічності зображеного в літературному творі» (Матковська, 2014: 329).

Як композиційний елемент художнього твору внутрішне мовлення постає складником модерністського принципу звернення до психіки героїв літературних творів, що спостерігаємо в психологічній прозі сучасних українських письменників. Яскравим прикладом реалізації такої манери письма слугують психобіографічні романи Степана Процюка про українських письменників - Василя Стефаника («Троянда ритуального болю»), Архипа Тесленка («Чорне яблуко») та Володимира Винниченка («Маски опадають повільно»). Ці твори належать до

«nсихобіографічної трилогї̈» письменника ци репрезентують спробу автора «подати власну психоінтерпретацію літературних персон <...> y стилі творення низки власних центральних героїв. Психоделічних, розчахнутих, затиснених між імперативом, покликом обов'язку і дротами комплексів, що походять з дитинства» (Пастух, н.д.).

Критики наголошують на психологічному аспекті романів, називаючи їхні частини психоісторіями письменницької душі. С. Процюка передусім цікавили особливості психотипу героїв, загадковий внутрішній світ, трагедія душі. Глибокий психологізм романів увиразнюють вдало представлені способи передавання чужої мови*, які впливають на емоційно-образне сприйняття творів читачем, презентують індивідуальний стиль, специфіку

* Синкретичні способи передавання чужої мови в ідіостилі С. Процюка проаналізовано в нашій статті (Шитик, 2017), де частково схарактеризовано й внутрішнє мовлення. 
мовної картини світу письменника та увиразнюють психологічну характеристику його героїв - Василя Стефаника, Архипа Тесленка та Володимира Винниченка.

Мета статті - комплексно проаналізувати способи передавання внутрішнього мовлення персонажів у психолінгвістичній проекції. Досягненню задекларованої мети сприяла реалізація таких завдань: обгрунтувати змістову багатозначність і галузеву полівекторність поняття «внутрішнє мовлення» з позицій психології, психолінгвістики, філософії, лінгвістики та літературознавства; диференціювати й описати два способи передавання внутрішнього мовлення - внутрішню пряму мову та невласне-пряму мову, умотивувати їхній синкретизм та окреслити психолінгвістичні характеристики; 3'ясувати функційно-стилістичний потенціал синкретичних способів передавання внутрішнього мовлення персонажів в ідіостилі Степана Процюка.

\section{Методи та методики дослідження}

У ході дослідження залучено як загальнонаукові, так і суто лінгвістичні та психолінгвістичні методи: аналіз і синтез - для обгрунтування теоретичних засад роботи; спостереження - для забезпечення процесу дослідження емпіричною інформацією, що необхідна для актуалізації нових проблем і подальшої їх перевірки; метод дефініиійного аналізу, за допомогою якого детерміновано зміст наукових визначень досліджуваних понять; лінгвістичного опису мовних фактів та метод класифікащії - для інвентаризації й систематизації способів передавання внутрішнього мовлення, характеристики їхньої специфіки; структурний метод, представлений методиками структурно-семантичного, компонентного та опозиційного аналізу, - для виокремлення спільного між мовними явищами та для побудови системи опозицій. Метод діалогічної інтерпретаціï тексту, використовуваний у психолінгвістичних дослідженнях, залучено для визначення місця тексту у творчості С. Процюка, інтерпретації авторського задуму й інтенцій,

«реконструкиї відображення в текстовій моделі уявної дійсності авторського світогляду, структури свідомості» (Селіванова, 2006: 332-333). 
Для визначення процедури дослідження важливими стали методологічні й навчально-методичні праці (Денисенко \& Чеботарев, 2008; Куранова, 2012; Леонтьев, 2003; Селіванова, 2006; Холод, 2019 та ін.), де 3'ясовано проблему типології сучасних наукових методів аналізу.

\section{Результати та дискусії}

Художній твір являє собою писемну мову автора, що містить авторську й чужу мову в різних варіаціях. Традиційно в лінгвістиці поняття чужої мови охоплює різноманітні синтаксичні конструкції, здатні найефективніше відтворити мовлення чи думки героя в авторському тексті. Глибина й багатоплановість зображення персонажів художнього твору можлива завдяки розкриттю ïхніх внутрішніх думок, переживань i прагнень. Такий спосіб репрезентації діалектики душі персонажа найвиразніше втілено у внутрішньому мовленні.

Під час аналізу текстового матеріалу використано науковотеоретичні положення про сутність внутрішнього мовлення 3 позицій психології, психолінгвістики, філософії, лінгвістики та літературознавства. Важливу роль для розуміння внутрішнього мовлення, зокрема процесів його породження та мовленнєвомисленнєвої діяльності, відіграли дослідження таких психологів та психолінгвістів (Ананьев, 2001; Ахутина, 1985; Баєв, 1966; Выготский, 1934; Гальперин, 1957; Жинкин, 1998; Калмикова, 2013; Леонтьев, 2003; Лурия, 2002; Соколов, 1968; Ehrich, 2006; Hickok, 2001) та ін.

Погляди на статус внутрішнього мовлення - неоднозначні. Більшість дослідників підтримує тезу Л. Виготського про те, що «внутрішнє мовлення - це мовлення для себе» на противагу зовнішньому - «мовленню для інших» (Выготский, 1934: 279) та положення про згорнутість і предикативність як диференційні ознаки внутрішнього мовлення (Там само). Б. Ананьєв, акцентуючи на залежності форм внутрішнього мовлення від виду мовної діяльності, заперечує тезу Л. Виготського про його абсолютну й чисту предикативність та розвиває положення про те, що логіко-синтаксична структура внутрішнього мовлення 
може бути різноманітною залежно від пізнавального змісту думки (Ананьев, 2001).

Чимало психологів уважають, що внутрішне мовлення не виконує комунікативної функції (Баєв, 1966), оскільки постає своєрідним етапом підготовки до зовнішнього мовлення на основі глибинних лексико-семантичних структур, а отже слугує моделлю потенційної комунікації. Внутрішнє мовлення, на думку Б. Баєва (1966), виконує функції обдумування, планування, регуляції діяльності, внутрішньої підготовки процесу спілкування та обміну думками. 3 огляду на рефлекторну природу та спосіб походження, дослідник акцентує на нерозривності зв'язку зовнішнього i внутрішнього мовлення, уважає останній різновид результатом диференціації функцій мови та визнає його вторинність, похідність від зовнішнього мовлення. Внутрішнє мовлення дає змогу організувати чуттєву діяльність людини, забезпечує «внутрішнє оброблення» чуттєвого матеріалу, допомагає впорядкувати його, мислено згрупувати та відібрати необхідне, оцінити діяльність 3 огляду на мету та відповідність дійсності (Савчин, 2015).

У психологічному ракурсі внутрішнє мовлення постає як особливий вид психічної діяльності, пов'язаний з усіма аспектами людської психіки: сприйняттям, мисленням, пам'яттю, почуттями, волею (Матковська, 2014). Психолінгвістична природа мовлення схарактеризована як складний динамічний процес, що об'єднує низку пов'язаних етапів: мотив, задум, внутрішнє програмування, лексико-семантичне розгортання, граматичне структурування, реалізація в зовнішньому мовленні (Артюшков, 2003). На думку науковця, внутрішнє мовлення виникає на етапі лексикосемантичного розгортання, коли ідеї проходять початковий етап вербалізації (там само).

Філософський підхід до розуміння суті внутрішнього мовлення грунтований на діалогічності й комунікативності як сутнісних ознаках людського мовлення (Платон, 1968; Шлегель, 1983) та взаємозалежності мови і мовлення. На діалогічності внутрішнього мовлення акцентовано і в психолінгвістичних студіях. Зокрема, Л. Калмикова, аналізуючи внутрішнє мовлення як мовленнємислення, пов'язує з ним внутрішній діалогізм мовленнєвої особистості. Мовленнєве мислення, висновує дослідниця, постає як складне динамічне ціле, у якому діалог думки і слова виявляється 
як рух через низку внутрішніх планів, як перехід від одного плану до іншого (Калмикова, 2013).

Способом художньої репрезентації внутрішнього мовлення, його своєрідною літературною моделлю вважають внутрішній монолог. Як зауважує 3. Лещишин, основні дискусії розгортаються навколо кількох проблем, як-от:

«взаємини між внутрішнім монологом і внутрішнім мовленням; невласне-пряме мовлення $i$ потік свідомості як різновиди внутрішнього монологу; внутрішній монолог $і$ потік свідомості як різновиди невласне-прямого мовлення; спроби ототожнення внутрішнього монологу $i$ потоку свідомості $i$, навпаки, принцииового розрізнення цихх понять» (Лещишин, 2009: 3).

Лінгвістичне тлумачення способів відтворення внутрішнього мовлення також грунтоване на різних засадах. За власнеграматичним підходом, це явище досліджують як структурний елемент тексту або окремого висловлення (Кодухов, 1957; Шульжук, 2001 та ін.), звертають увагу на прагматичні характеристики, способи й засоби вираження (Арутюнова, 1992). Тенденція до переходу в комунікативну парадигму посилила увагу до комунікативної ситуації, теорії мовленнєвих актів (Винокур, 2007; Максимова, 2005), поняття внутрішнього дискурсу (Бацевич, 2003), теорії діалогізму (Бахтин, 1986; Hermans, 2003; Puchalska-Wasyl, 2006) та автокомунікації (Лотман, 1999) тощо.

У сфері чужої мови повністю не усталена термінологія: пряму, непряму, невласне-пряму мову та ін. називають способами, формами, прийомами передавання чужих висловлень, подеколи їх кваліфікують як різновиди або види чужої мови. Плутанину спричинило некоректне застосування термінів «внутрішній монолог» i «внутрішнє мовлення». На думку 3. Лещишин,

«використовуючи термін «внутрішне мовлення» як родовий, дослідники не сходяться щзодо його видових складників. Через термінологічну синонімію виникли труднощі в розмежуванні понять «внутрішній монолог», «потік свідомості», «невласнепряме мовлення» (Лещишин, 2009: 3-4).

У лінгвістиці переважно не розрізняють невласне-пряму мову i внутрішній монолог, останній кваліфікують як мовностилістичну категорію, мову персонажа, не адресовану комусь, а вимовлену на 
самоті, переважно подумки. Н. Королевич стверджує, що невласнепряму мову використовують як для передавання безпосередніх висловів персонажів (звернені монологи, діалоги й колективні багатоголосі висловлення, або полілоги), так i для розкриття внутрішнього світу героїв, їхніх думок, прагнень і переживань (внутрішні монологи) (Королевич, 1968).

Переконливою $є$ думка В. Рінберг, що внутрішній монолог не можна ототожнювати 3 невласне-прямою мовою попри те, що їх зближують змістова спрямованість, лексико-фразеологічний склад і синтаксично-стилістична специфіка, яка межує з емоційноекспресивним забарвленням категорії (Ринберг, 1971).

Кваліфікаційними ознаками типології текстових різновидів внутрішнього мовлення є його обсяг, спосіб інтеграції в тексті, зміст та особливості використання в ньому лексико-граматичних засобів (Матковська, 2014). Неперервний процес внутрішньої комунікації особистості забезпечують такі основні форми внутрішнього мовлення: просте внутрішне реплікування, внутрішній діалог i внутрішній монолог (Сергеева, 2009) або потік свідомості, внутрішній монолог, автодіалог і малі вкраплення внутрішнього мовлення (Кухаренко, 1988) тощо.

Визнаючи естетичну значущість і важливість існування на сторінках художніх творів внутрішнього мовлення героїв, багато дослідників об'єднують внутрішній монолог i невласнепряму мову в один художній прийом на підставі їхньої функційної схожості. Нам імпонує розрізнення Г. Рустамовою двох стилістичних форм внутрішнього мовлення персонажів: зображене внутрішне мовлення як різновид невласне-прямої мови - частково трансформовані внутрішні репліки й думки персонажа в умовах авторської розповіді - та внутрішню пряму мову $^{*}$ (за іншою термінологією - внутрішній монолог). Внутрішня пряма мова протиставлена зовнішній за ознакою вимовлена/ невимовлена. Основою лінгвостилістичних розбіжностей між ними Г. Рустамова вважає функційно-психологічну взаємодію, що полягає в генетичній залежності внутрішнього мовлення від зовнішнього (Рустамова, 2006).

\footnotetext{
* Логічніше, на нашу думку, послуговуватися саме цим терміном, адже поняття «внутрішній монолог» відображає форму вираження внутрішнього мовлення героя, а воно не завжди монологічне.
} 
Загальновідомо, що будь-який текст $\epsilon$ писемною мовою автора, яка містить два основні різновиди - авторську мову i чужу. Авторська мова із синтаксичного погляду слугує основою розповіді, канвою твору, куди вставлені інші способи викладу, що мають свої засоби вираження. До того ж засоби вираження прямої мови, невласне-прямої мови тощо, з огляду на їхню синтаксичну залежність від авторського тексту, обов'язково мають подвійний характер: $з$ одного боку, вони виділяють ці категорії з авторського контексту, $з$ іншого - поєднуються 3 ним. 3 огляду на це, логічно розмежовувати способи передавання чужої мови і способи викладу в художньому творі.

Загалом усі конструкції 3 чужою мовою можна вважати синкретичними утвореннями, оскільки для них характерний синтез диференційних ознак або різних способів передавання чужої мови, або способів їі викладу в художньому творі, чи обох водночас. На цій підставі виокремлюємо в межах конструкцій із чужою мовою два види протиставлень: «пряма мова//непряма мова» та «мова персонажів//мова автора». Досліджувані нами способи передавання внутрішнього мовлення репрезентовані в обох системах опозиції: невласне-пряма мова перебуває в проміжній ланці за обох типів протиставлення, а внутрішня пряма мова - на периферії прямої мови та на периферії мови персонажів, тобто виявляє перевагу їхніх ознак.

Перебуваючи в полі взаємодії прямої i непрямої мови, конструкції 3 внутрішньою прямою та невласне-прямою мовою різнопланово ілюструють вияви змістового, формального та реченнєво-текстового синкретизму (докладніше див.: Шитик, 2014), тобто $є$ синкретичними в синтаксичному плані. Водночас вони виявляють і синкретизм змісту, оскільки поєднують дві змістові площини - авторську і персонажа, а отже репрезентують авторський виклад мови героїв.

За функційної спільності внутрішньої прямої мови і невласнепрямої мови, тобто здатності відтворювати думки й почуття персонажа, кожен із цих способів має свою специфіку, зокрема: особливі стилістичні відтінки (внутрішня пряма мова створює широкі можливості характерологічного опису героїв, а стилістичні можливості невласне-прямої мови розширені в бік вираження об'єктивного джерела художнього твору); графічне оформлення 
(наявність спеціальної пунктуації, спільної для зовнішньої та внутрішньої прямої мови, і відсутність їі в зображеній внутрішній мові як формі невласне-прямої мови) (Рустамова, 2006).

Внутрішня пряма мова, або внутрішній монолог, $є$

«складною формою односторонньої мовленнєвої взаємодї індивіда з самим собою» (Матковська, 2014: 330).

Для опису внутрішнього монологу Ю. Сергеєва пропонує такі критерії: ступінь контамінації суб'єктно-авторських перспектив (прямий i непрямий внутрішній монолог), напрям руху мовлення i мислення персонажа (ретроспективний, актуальний і проспективний внутрішній монолог), суб'єктний діапазон, обсяг репродукованого внутрішнього мовлення (персональний i колективний внутрішній монолог) (див. докладніше: Сергеева, 2009).

Внутрішню пряму мову структурно вирізняє «стиснутий» синтаксис, наявність питальних та окличних речень, фрагментарність вираження думок, емоційна насиченість, напр.:

- Мамо! Тепер би мені твоя ласка, твоя любов... Нащуо вчили мене бути добрим $і$ любити людей, мамо?! Нема добра в людських сериях... кожне лише про свою икуру дбає... нема справедливості ні в нас, ні між київяли, город великий, а такі всі байдужі, мамо... йдуть собі кудись пани, сало аж двигтить на коміриях, вола такі поод’̈̈дувані, щзо крий Боже... («Чорне яблуко»).

Роздуми героїв, представлені у формі внутрішньої прямої мови, часто не мають належного пунктуаційного оформлення за зразком прямої мови, відсутні також слова автора, натомість їх маркує в тексті графічне оформлення - курсивом. Очевидно, ці зразки також можна вважати внутрішньою прямою мовою, відтвореною, однак, за іншим типом. Напр.:

...вона пише і плаче, дивлячись на його фото. Чомусь мені стало тебе так жалко, захотілося приголубить тебе... Я хочу бачить тебе і... изе недосяжна мрія... («Маски опадають повільно»).

Внутрішня мова героїв у художньому тексті постає не тільки для відтворення монологічних роздумів героя, але i як форма внутрішньої, завуальованої розмови героїв між собою. І. Клюканов уважає, що діалогічність комунікації передбачає існування в 
ролі можливого об’єкта будь-якої істоти, із якою ми вступаємо в розмову (діалог), тобто Іншого. У цьому ракурсі комунікація - це повсякденний, звичний процес, учасниками якого стають будь-які об’єкти (Клюканов, 2009).

Цікавими є міркування 3. Лещишин, яка розрізняє діалогічність внутрішнього монологу та його діалогізованість. Діалогічність, на думку дослідниці,

«полягає в особливостях изього способу викладу як моделі
автокомунікативного за своєю природою внутрішнього
мовлення» (Лещишин, 2010: 157).

3 огляду на це у внутрішньому монолозі може бути реалізована як автокомунікація (розмова із собою), так і своєрідна віртуальна комунікація з іншим.

«Водночас таке мовлення може тривати як потениійна (наприклад, підготовка до майбутнього чи продовження попереднього спілкування $з$ іншим персонажем тощо) чи віртуальна комунікація (наприклад, звернення до риторичної чи вигаданої особи тощуо)» (там само).

Психобіографічні романи С. Процюка містять численні випадки такої віртуальної комунікації, напр.:

Він [Архип] якось перестав згадувати Оленку, хіба щзо в снах вона ще відвідувала його, і заспокоївся. < ...

Може, нічого насправді не було?

- Може, і не було!.. - відлунювало десь у садах.

- Може, вона врешті забула про мене? - якось болісно $i$ натхненно перекривилося його лице.

- Вона врешті забула про тебе... - відкривали свої ротики перезрілі осінні яблука, котячись йому під ноги.

$<\ldots>$ Він подумав, щзо Оленки вже немає..

- Оленки вже немає... - тихо шепотіло повітря («Чорне яблуко»).

Діалогізованість, або зовнішню діалогічність, 3. Лещишин вважає похідним явищем, що полягає у вияві діалогічності внутрішнього монологу на рівні структурної організації, граматично-синтаксичних засобів, зокрема у використанні форм другої та третьої особи для звертання до себе як до іншого. Однак найскладнішим за будовою є монолог, побудований як власне діалог, 
тобто поділений на репліки. Саме в такому монолозі найбільше виражена діалогічність, вона має різне навантаження: персонаж може просто згадувати розмову, що мала місце в тексті раніше, або моделювати потенційну комунікацію 3 іншим персонажем (Лещишин, 2010).

В аналізованих романах Степана Процюка репрезентовано різні способи вияву зовнішньої діалогічності. Зокрема, поширеними $€$ конструкції, у яких герой для звертання до себе використовує форму другої особи однини, напр.:

Крізь тебе, мимо тебе, всередині тебе струменіло світло. Ти міг годинами дивитися в одну точку. Навколо все було прекрасним.

Чому так не сталося раніме? Хто це зробив? Що ие? Невже та безсонна ніч була останньою агонією перед світанком? Але... вже сутінки... ти вже немолодий... хіба світанок приходить під час сутінків? Може, ти став юнаком з невразливим тілом $i$ серием? («Маски опадають повільно»).

Прикладом потенційної комунікації може бути уявна розмова представників «покутської трійці»:

...Пізніше романтичні літературознавиі витворять міф про «покутську трійщю». Мовляв, їх троє, у шикарних костюмах, збиралося на тлі мальовничої природи і кожен казав:

- Дорогі братове! Як ми можемо поліпшити мужицьку долю?

- Будемо писати про них!

- Але якщз ми трійия, то мусимо хоч раз на тиждень збиратися і говорити...

- Про злиденний люд! Про слабку покутську літературу! Про намі шедеври!

- Вирішили! («Троянда ритуального болю»).

Уважаємо за доцільне вирізняти дві форми представлення внутрішньої прямої мови:

- монологічну, напр.:

...таточку рідний! Не раз $і$ не десять стояв мені в очах ией вам прихід $і$ иі мимовільні сльози, коли ви відвернулися до стіни... а потім справили зодів мені, мама комірия висмикнула із сорочки... я не знав, як ходити в такому одязі, ие ж не лаиур'я якесь... татусю любий... які ви раді були тоді, які горді й щасливі, щзо можете одправить мене до школи... яка була мама горда, навіть підняла голову так величаво, мов королева... 
Андрійко й Ганнуся раділи, щее живі були... так могло бути завжди... але злидні, прокляті дуки виссали вашу й мою силу... («Чорне яблуко»);

- діалогічну, напр.:

...а в небесах $і$ Василько, і Настя, і їхня мама, щуо ї̈ жовнірська куля вбила, такі лагідні, із білими усмішками янголів $i$ чорною кров'ю біля серия... він підходить до них - $i$ хлопчик питає: «Вуйку, чого ви вбили у вашій новелі мою маму?»... «То не я, дитино, то война ї̈ вбила»... «Война?»... «А з тобою $i$ сестричкою щуо відтак сталося?»... «Ми йшли, йшли... спочатку маленька кулька вцілила Настю... вона дуже кричала... я тягнув ï̈ на собі... але потому затихла... все затихло... я ліг і плакав»... «A потому?»... «А потому... мені щуось снилося біле $i$ високе... а відтак я вчув біль коло серия... затих... а потому опинився mут, коло своєї мами і Насті»... («Троянда ритуального болю»).

У наведеному фрагменті частина тексту реалізована засобами внутрішнього персонажного мовлення, різновидом якого $\epsilon$ внутрішній діалог/автодіалог -

«відтворення в мовленні індивіда декількох смислових позицій або композииійних точок зору, щзо взаємодіють між собою» (Матковська, 2014: 331).

Діалогічна форма внутрішньої прямої мови часто ілюструє сильне внутрішнє напруження, розлади психіки, балансування мислення на межі свідомого та несвідомого. Показовим щодо цього є потенційний (уявний) діалог Стефаникових трьох «Я», напр.: <..>

Перше «Я》: Кожна людина лишає після себе цุвинтар, щзо складається з розчарувань і жалю стосовно неї інших...

Друге «Я»: Але селян на папері любити легше, ніж реальних людей?

Третє «Я»: А може, ти нікого не любиш, як кожний невротик, бо не можеш? I лише шалено, до безтями прикриваєшся любов'ю?

Перше «я»: Без любові я би не написав ні рядка... Мене демонізують та ідеалізують.

Друге «Я》: Як і кожного великого талантом...

Трете «я»: Ніколи не хваліть мене! Мені від сього чомусь стидно і лячно. <..> («Троянда ритуального болю»). 
Внутрішнє спілкування 3 alter ego зумовлене потребою розв'язати світоглядні питання, забезпечити структурне оформлення, розгортання, логічні зв'язки й актуалізацію декількох світоглядних поглядів, що забезпечує композиційну поліфонічність художнього твору.

Виражаючи приховані судження й переживання, прагнення та сподівання героя, внутрішня пряма мова дає змогу читачеві стати свідком внутрішньої, психологічної діяльності персонажів. Такий контакт між читачем і персонажем, як зазначає Г. Рустамова, може бути налагоджений автором художнього твору двома шляхами:

1) або за його ілюзорної відсутності, повної відмови від «втручання» в думки героя, тобто через внутрішній монолог (за нашою термінологією - внутрішню пряму мову);

2) або контамінацією, зливанням голосів автора й дійової особи в невласне-прямій мові (Рустамова, 2006).

У мовознавстві донедавна побутувало визначення невласнепрямої мови як різновиду непрямої, або самостійної категорії, або конструкції проміжного характеру, що постає внаслідок зближення прямої і непрямої мови (Бклаховський, 1951; Ринберг, 1971 та ін.). Основною розбіжністю наявних дефініцій невласне-прямої мови $€$ потрактування статусу цієї мовної категорії як способу передавання чужої мови, особливого стилістичного прийому, стилістичного засобу тощо."

Оскільки невласне-пряма мова $\epsilon$ двоплановою категорією, логічно трактувати іï сутність у двох площинах: у площині протиставлення «мова персонажів//мова автора» - як спосіб викладу, за якого чужа мова формально зливається 3 авторською, що зумовлює поєднання суб'єктивних планів автора й героя в однаковому співвідношенні (проміжна ланка між авторською та чужою мовою); у площині протиставлення «пряма мова//непряма мова» прийнятна така дефініція: це особливий синкретичний спосіб передавання чужої мови, що поєднує особливості прямої мови (за змістом) і непрямої мови (за формою).

Невласне-пряма може мати різний ступінь наближення до прямої мови, що дає підстави розмежовувати два різновиди невласне-прямої мови залежно від стилістичних орієнтирів:

* Докладний аналіз наявних дефініцій невласне-прямої мови представлений у нашій статті (Шитик, 2010). 
«літературний» і «характерологічний» (Вавринюк, 2004: 45-47). Така типологія збігається 3 виокремленими Г. Рустамовою двома варіантами: «авторською» та «персональною» невласнепрямою мовою (Рустамова, 2006: 387), що відповідає іiі двовекторному трактуванню.

Для першого різновиду характерна незначна структурна нівеляція внутрішнього монологу героя в бік авторської розповіді. До літературного зараховують

«фрагменти художнього тексту, щзо відображають позицію героя $i$ з якими пов'язане повне чи часткове «перевтілення» оповідача у свого персонажа» (Вавринюк, 2004: 45).

Такі фрагменти передають глибоко приховані, інтимні моменти психічного i духовного життя персонажа, насичені елементами чужого слова, напр.:

Достеменно знав лише те, щзо був чесний з усіма своӥми (чи дійсно свойми?) жінками. Ніколи не брехав. <... Бо направду людям не треба правди або брехні. Людям треба щастя. А він не крамар, щзо торує щңастям. Не казанова, який ощасливлює навіть одним харизматичним поцілунком. Не донжуан, щзо руйнує сподівання. Він - вічний подорожній. Він знає все $і$ не знає нічого. Він ще не мудрець, але вже не переросток. Тюрми $i$ безгрошів'я, спади і відродження популярності таки гартують його, а не донищують («Маски опадають повільно»).

«Персональна», або «характерологічна», невласне-пряма мова демонструє індивідуалізацію мисленнєво-мовленнєвого плану персонажів (Рустамова, 2006), а тому вона наближена до прямої мови, про що свідчить уведення питальних та окличних речень, що часто функціюють як неповні, парцельовані чи перервані структури, вкраплення просторіч, оцінно-експресивної лексики, напр.:

Він [А. Тесленко] хотів ще щось сказати, але сльози котилися горохом, застилали зір і довкілля. Мамо рідна, щзо ж вона таке каже... яку жінку він може знайти, коли уявляє своє життя лише з нею... як так можна сказать!.. наче жінка - це щось таке, що можна пересунуть, змінить чи забуть за власним наказом... Коли він прокидається з їі іменем на устах $i$ засинає з їі іменем, то про яку жінку може йтися? Комусь зав'язувати світ, мати якусь відповідальність за сімейні статки, ще 
когось терпіть, окрім себе самого... Та ніколи! Ні-ко-ли! («Чорне яблуко»).

Створюючи психологічні портрети своїх героїв - людей iз непростими, надзвичайно загостреними відчуттями справедливості, краси, із драматичними долями - Степан Процюк обирає для передавання цих протиріч «напрочуд вдалу форму - внутрішнього монологу, який нерідко переходить у внутрішній діалог автора зі своїм героєм» (Андрусяк, н. д.), набуває форми невласне-прямої мови, поєднує й інші синкретичні способи відтворення чужої мови. Часто внутрішнє мовлення персонажа репрезентує обидва способи, напр.:

Були хвилі, коли Євгенія починала ненавидіти свого коханого мучителя. Може, піти до знахарок, до ворожки, але так, щуоб ніхто не знав? Може, ворожка вишепче? Може, то пристріт якийсь, а не любов? Вона нічого не знає... вона у якійсь волосяниці, щзо тримає ї̈, у залізному панцирі... Васильку, рідний, де ти, порятуй мене, бідну, благаю тя, <..> я не можу їсти, не можу спати, мені нецікаво говорити, бо нема мого Василька ніде $<\ldots>$ Якщуо його не буде $і$ далі... Пойхати до Кракова, впасти йому в ноги, просити? Вона би зробила так, але не пустять, засміють... Що їй дівоча гордість, коли не хочеться жити? Ти чуєш мене, кохании? Що ти робиш зараз у своєму Кракові? < .. > («Троянда ритуального болю»).

Форма невласне-прямої мови дає авторові змогу не тільки відтворити чужу мову, зберігши в ній індивідуальні особливості мови героїв, а й повніше та глибше передати думки й прагнення героїв. Використання невласне-прямої мови сприяє художньому розв’язанню проблеми напруженості між мовою автора й мовою героя, допомагає налагодити взаємопереходи в їхньому діалозі. Межі між планом автора та планом персонажа стають розмитими, завдяки чому скорочується дистанція між оповідачем i героєм, героєм і читачем.

\section{Висновки}

Інтегрований підхід до розуміння суті внутрішнього мовлення грунтований на його діалогічності, віртуальній комунікативності й автокомунікативності, взаємозалежності мови і мовлення. 
Функційно-стилістичний потенціал конструкцій, що репрезентують внутрішнє мовлення персонажів, надзвичайно потужний. Широковживані в психобіографічних романах Степана Процюка способи відтворення внутрішнього мовлення внутрішня пряма мова й невласне-пряма мова - ускладнюють синтаксичний та експресивний малюнки речення, дають додатковий лінгвостилістичний матеріал для створення психологічних портретів героїв, сприяють художньому розв'язанню проблеми напруженості між мовою автора й мовою героя, допомагають налагодити взаємопереходи в їхньому діалозі, скорочують дистанцію між оповідачем i героєм, героєм i читачем. Внутрішнє мовлення настільки насичене емоціями, що для глибшого проникнення у внутрішній світ персонажів й опису психологічного стану автор послуговується цими синкретичними способами.

Перспективу подальших наукових пошуків убачаємо в дослідженні специфічних способів відтворення чужої мови, зокрема цитатних вкраплень, потужно представлених в аналізованих романах.

\section{Література}

Ананьев, Б.Г. (2001). Психология чувственного познания. Москва: Наука.

Андрусяк, I. (н.д.). Геній крізь призму «душезнавства». Режим доступу: http:// dyskurs.narod.ru/Stepan-Stefanyk.htm

Артюшков, И.В. (2003). Внутренняя речь и ее изображение в художественной литературе: на материале романов Ф.М. Достоевского и Л.Н. Толстого. Москва: Московский педагог. гос. ун-т.

Арутюнова, Н.Д. (1992). Диалогическая модальность и явление цитации. Человеческий фактор в языке. Коммуникация, модальность, дейксис (с. 52 79). Москва: Наука.

Ахутина, Т.В. (1985). Единицы речевого общения, внутренняя речь, порождение речевого высказывания. Исследования речевого мылиления в психолингвистике (с. 99-116). Москва: Наука.

Баєв, Б.Ф. (1966). Психологія внутрішнього мовлення. Київ: Радянська школа.

Бахтин, М.М. (1986). Эстетика словесного творчества. Москва: Искусство.

Бацевич, Ф.С. (2003). Нариси з комунікативної лінгвістики. Львів: Вид. центр Львівського національного університету ім. І. Франка.

Булаховський, Л.А. (Ред.). (1951). Курс сучасної української літературної мови (Т. 2 : Синтаксис). Київ: Радянська школа.

Вавринюк, Т. (2004). Невласне-пряма мова як засіб суб'єктивації тексту. Мандрівецьь, 2, 45-47.

Винокур, Т.Г. (2007). Говорящий и слушающий: Варианты речевого поведения (3-е изд.). Москва: Изд-во ЛКИ. 
Выготский, Л.С. (1934). Мышление и речь (психологические исследования). Москва; Ленинград: Огиз-Соцэкгиз.

Гальперин, П.Я. (1957). К вопросу о внутренней речи. Доклады Академии педагогических наук РСФСР, 4, 67-79.

Денисенко, В.Н., \& Чеботарев, Е.Ю. (2008). Современные психолингвистические методы анализа речевой коммуникачии. Москва: РУДН.

Жинкин, Н.И. (1998). Язык - речь - творчество: Исследования по семиотике, психолингвистике, поэтике. Москва: Лабиринт.

Калмикова, Л.О. (2013). Проблеми мислення, мовлення і внутрішнього діалогізму особистості. Psycholinguistics. Психолінгвістика. Психолингвистика, 14, 185-197.

Клюканов, И.Э. (2009). О диалогичности коммуникации. Bonpocbl психолингвистики, 9, 110-114.

Кодухов, В.И. (1957). Прямая и косвенная речь в современном русском языке. Ленинград: Учпедгиз (Ленингр. отд-ние).

Королевич, Н.Ф. (1968). Невласне-пряма мова в романі А. Головка «Бур'ян». Синтаксична будова української мови (с. 163-173). Київ: Наукова думка.

Куранова, С.І. (2012). Основи психолінгвістики. Київ: Академія.

Кухаренко, В.А. (1988). Интерпретация текста (2-е изд., перераб.). Москва: Просвещение.

Леонтьев, А.А. (2003). Основы психолингвистики (3-е изд.). Москва: Смысл; Санкт-Петербург: Лань.

Лещишин, 3.I. (2010). Внутрішній монолог як модель комунікації. Наукові записки, 16, 148-161.

Лещишин, 3.I. (2009). Внутрішній монолог як форма літературного викладу. Автореф. дис. канд. філол. наук. Львів.

Лотман, Ю.М. (1999). Внутри мыслящих миров. Человек - текст - семиосфера история. Москва: Языки русской культуры.

Лурия, А.Р. (2002). Письмо и речь: Нейролингвистические исследования. Москва: Издательский центр «Академия».

Максимова, Н.В. (2005). «Чужая речь» как коммуникативная стратегия. Москва: Изд. центр РГГУ.

Матковська, Г. (2014). Композиційно-мовленнєві форми фіксації внутрішнього мовлення в художніх творах В. Вулф. Наукові записки Вінницького державного педагогічного університету імені Михайла Кочюбинського. Серія: Філологія (мовознавство), 19, 328-333.

Пастух, Б. (н.д.). Психографія у шатах слова. Режим доступу: http://www.bukvoid. com.ua/reviews/books/ 2010/07/19/

Платон. (1968). Теэтет. Сочинения. А.Ф. Лосев \& В.Ф. Асмус (Ред.). (Т. 1-3). (Т. 2). Москва: Мысль.

Ринберг, В.Л. (1971). Несобственно-прямая речь и внутренний монолог в сфере средств передачи чужого высказывания. Вопросы синтаксиса русского языка (c. 193-202). Ростов-на-Дону : Ростовский н/Д. гос. пед. ин-т.

Рустамова, Г.А. (2006). Лингвистические особенности несобственно-прямой речи в художественном тексте. Баку: Kitab alemi.

Савчин, О.М. (2015). Проблема внутрішнього мовлення в психолінгвістичній спадщині Б.Ф. Баєва. Psycholinguistics. Психолінгвістика. Психолингвистика, $17,127-134$.

Селіванова, О. (2006). Сучасна лінгвістика: термінологічна енциклопедія. Полтава: Довкілля-К. 
Сергеева, Ю.М. (2009). Внутренняя речь как особая форма языкового общения: на материале англоязычной художественной литературы. Автореф. дисс. д-ра филол. наук. Москва.

Соколов, А.Н. (1968). Внутренняя речь и мышление. Москва: Просвещение.

Холод, О. (2019). Завдання психолінгвістичної методології досліджень і квантовий підхід. Psycholinguistics. Психолінгвістика. Психолингвистика, 25 (2), 338370. https://doi.org/10.31470/2309-1797-2019-25-2-338-370

Шитик, Л. (2014). Синхронна перехідність синтаксичних одиниць в украӥнській літературній мові. Черкаси: видавець Чабаненко Ю.А.

Шитик, Л.В. (2010). Синкретизм способів передавання внутрішнього мовлення. Вісник Черкаського університету. Серія : Філологічні науки, 193, 12-22.

Шитик, Л.В. (2017). Синкретизм способів передавання чужої мови в ідіостилі Степана Процюка. Мовознавчий вісник, 22-23, 15-23.

Шлегель, Ф. (1983). Эстетика. Философия. Критика. Ю.Н. Попов (Ред.). (Т. 1-2). (Т. 2). Москва: Искусство.

Шульжук, Н. (2001). Синтаксичні особливості конструкцій з чужою мовою у діалозі. Лінгвістичні студіï, 8, 109-112.

Ehrich, J.F. (2006). Vygotskyan inner speech and the reading process. Australian Journal of Educational and Developmental Psychology, 6, 12-25.

Hermans, H.J.M. (2003). The construction and reconstruction of a dialogical self. Journal of Constructivist Psychology, 16, 89-130. https://doi. org/10.1080/10720530390117902

Hickok, G. (2001). Functional Anatomy of Speech Perception and Speech Production: Psycholinguistic Implications. Journal of Psycholinguistic Research, 30, 225-235. https://doi.org/10.1023/A:1010486816667

Puchalska-Wasyl, M. (2006). Nasze wewnętrzne dialogi. O dialogowości jako sposobie funkcjonowania człowieka. Wrocław: Wydawnictwo Uniwersytetu Wrocławskiego [in Polish].

\section{References}

Ananev, B.G. (2001). Psihologiya chuvstvennogo poznaniya [Psychology of sensory knowledge]. Moscow: Nauka [in Russian].

Andrusiak, I. (n.d.). Henii kriz pryzmu «dusheznavstva» [The genius through the prism of «soul-searching»]. Retrieved from http://dyskurs.narod.ru/Stepan-Stefanyk.htm [in Ukrainian].

Artyushkov, I.V. (2003). Vnutrennyaya rech $i$ ee izobrazhenie $v$ hudozhestvennoy literature: na materiale romanov F.M. Dostoevskogo i L.N. Tolstogo [Inner speech and its image in fiction: based on the novels by F.M. Dostoevsky and L.N. Tolstoy]. Moscow: Moskovskiy pedagog. gos. Universitet [in Russian].

Arutyunova, N.D. (1992). Dialogicheskaya modalnost i yavlenie tsitatsii [Dialog modality and the phenomenon of citation]. Chelovecheskiy faktor $v$ yazyike. Kommunikatsiya, modalnost, deyksis - The human factor in the language. Communication, modality, deixis. (pp. 52-79). Moscow: Nauka [in Russian].

Ahutina, T.V. (1985). Edinicy rechevogo obshcheniya, vnutrennyaya rech, porozhdenie rechevogo vyskazyvaniya [Units of speech communication, internal speech, generation of speech utterance]. Issledovaniya rechevogo myshleniya $v$ 
psiholingvistike - Studies of speech thinking in psycholinguistics (pp. 99-116). Moscow: Nauka [in Russian].

Baiev, B.F. (1966). Psykholohiia vnutrishnoho movlennia [Psychology of internal speech]. Kyiv: Radianska shkola [in Ukrainian].

Bahtin, M.M. (1986). Estetika slovesnogo tvorchestva [Aesthetics of verbal creativity]. Moscow: Iskusstvo [in Russian].

Batsevych, F.S. (2003). Narysy z komunikatyvnoi linhvistyky [Essays on communicative linguistics]. Lviv: Vydavnychyi tsentr Lvivskoho natsionalnoho universytetu im. I. Franka [in Ukrainian].

Bulakhovskyi, L.A. (Ed). (1951). Kurs suchasnoi ukrainskoi literaturnoi movy [The course of modern Ukrainian literary language]. (Vols. 2). Kyiv: Rad. shkola [in Ukrainian].

Vavryniuk, T. (2004). Nevlasne-priama mova yak zasib subiektyvatsii tekstu [Non-proper direct speech as a means of text subjection]. Mandrivets Mandrivets, 2, 45-47 [in Ukrainian].

Vinokur, T.G. (2007). Govoryaschiy $i$ slushayuschiy: Variantyi rechevogo povedeniya [Speaker and listener: variants of verbal behavior]. (3-rd ed., rev.). Moscow: Izd-vo LKI [in Russian].

Vyigotskiy, L.S. (1934). Myishlenie i rech (psihologieskie issledovaniya) [Thinking and Speaking (Psychological Studies)]. Moscow; Leningrad: Ogiz-Sotsekgiz [in Russian].

Galperin, P.Ya. (1957). K voprosu o vnutrennej rechi [To the question of internal speech]. Doklady Akademii pedagogicheskih nauk RSFSR - Reports of the Academy of Pedagogical Sciences of the RSFSR, 4, 67-79 [in Russian].

Denisenko, V.N., \& Chebotareva, E.Yu. (2008). Sovremennye psiholingvisticheskie metody analiza rechevoj kommunikacii [Modern psycholinguistic methods of analysis of speech communication]. Moscow: RUDN [in Russian].

Zhinkin, N.I. (1998). Yazyk - rech - tvorchestvo: Issledovaniya po semiotike, psiholingvistike, poetike [Language - Speech - Creativity: Studies on semiotics, psycholinguistics, poetics]. Moscow: Labirint [in Russian].

Kalmykova, L.O. (2013). Problemy myslennia, movlennia i vnutrishnoho dialohizmu osobystosti [Problems of thinking, speaking and internal dialogism of the individual]. Psikholingvistika - Psycholinguistics, 14, 185-197 [in Ukrainian].

Klyukanov, I.E. (2009). O dialogichnosti kommunikatsii [About dialogism of communication]. Voprosyi psiholingvistiki - Psycholinguistics Issues, 9, 110-114 [in Russian].

Koduhov, V.I. (1957). Pryamaya $i$ kosvennaya rech $v$ sovremennom russkom yazyike [Direct and reported speech in modern Russian]. Leningrad: Uchpedgiz (Leningr. otd-nie) [in Russian].

Korolevych, N.F. (1968). Nevlasne-priama mova v romani A. Holovka «Burian» [Non-proper direct speech in A. Holovko's novel «Weed»]. Syntaksychna budova ukrainskoi movy - Syntactic structure of the Ukrainian language (pp. 163-173). Kyiv: Naukova dumka [in Ukrainian].

Kuranova, S.I. (2012). Osnovy psykholinhvistyky [Fundamentals of psycholinguistics]. Kyiv: Akademiia [in Ukrainian].

Kuharenko, V.A. (1988). Interpretatsiya teksta [Text interpretation] (2-nd. ed.). Moscow: Prosveschenie [in Russian].

Leontev, A.A. (2003). Osnovy psiholingvistiki [Fundamentals of Psycholinguistics] (3-rd ed., rev.). Moscow: Smysl; SPb.: Lan' [in Russian]. 
Leshchyshyn, Z.I. (2010). Vnutrishnii monoloh yak model komunikatsii [Internal monologue as a model of communication]. Naukovi zapysky - Scientific records, 16, 148-161 [in Ukrainian].

Leshchyshyn, Z.I. (2009). Vnutrishnii monoloh yak forma literaturnoho vykladu [Internal monologue as a form of literary presentation]. Extended abstract of Candidate's thesis. Lviv [in Ukrainian].

Lotman, Yu.M. (1999). Vnutri myslyaschih mirov. Chelovek - tekst - semiosfera istoriya [Inside the thinking worlds. Human being - text - semiosphere history]. Moscow: Yazyki russkoy kul'tury [in Russian].

Luriya, A.R. (2002). Pismo i rech: Nejrolingvisticheskie issledovaniya [Writing and speech: neuro-linguistic research]. Moscow: Izdatel'skij centr «Akademiya» [in Russian].

Maksimova, N.V. (2005). «Chuzhaya rech» kak kommunikativnaya strategiya ["Another's speech» as a communicative strategy]. Moscow: Izd. centr RGGU [in Russian].

Matkovska, H. (2014). Kompozytsiino-movlennievi formy fiksatsii vnutrishnoho movlennia v khudozhnikh tvorakh V. Vulf [Compositional-Speech Forms of Fixation of Internal Speech in Art Works by W. Wolff]. Naukovi zapysky Vinnytskoho derzhavnoho pedahohichnoho universytetu imeni Mykhaila Kotsiubynskoho. Seriia: Filolohiia (movoznavstvo) - Scientific notes of Vinnytsia Mykhailo Kotsyubynsky State Pedagogical University. Series: Philology (Linguistics), 19, 328-333 [in Ukrainian].

Pastukh, B. (n.d.). Psykhohrafiia u shatakh slova [Psychography in garments of the word]. Retrieved from http://www.bukvoid.com.ua/reviews/books/ 2010/07/19/ [in Ukrainian].

Platon. (1968). Teetet. Sochineniya [Theatet. Compositions]. A.F. Losev \& V.F. Asmus (Eds.). (Vols. 2). Moscow: Mysl [in Russian].

Rinberg, V.L. (1971). Nesobstvenno-pryamaya rech i vnutrenniy monolog v sfere sredstv peredachi chuzhogo vyskazyvaniya [Non-proper direct speech and an internal monologue in the sphere of means of transmitting someone's utterance]. Voprosy sintaksisa russkogo yazyka - Questions of the Russian language syntax (pp. 193-202). Rostov-na-Donu: Rostovskiy-na-Donu gos. ped. in-t [in Russian].

Rustamova, G.A. (2006). Lingvisticheskie osobennosti nesobstvenno-pryamoy rechi $v$ hudozhestvennom tekste [Linguistic features of non-proper direct speech in the literary text]. Baku: Kitab alemi [in Russian].

Savchyn, O.M. (2015). Problema vnutrishnoho movlennia v psykholinhvistychnii spadshchyni B.F. Baieva [The problem of internal speech in the psycholinguistic legacy of B.F. Bayev]. Psikholingvistika - Psycholinguistics, 17, 127-134 [in Ukrainian].

Selivanova, O. (2006). Suchasna linhvistyka: terminolohichna entsyklopediia [Modern linguistics: a terminological encyclopedia]. Poltava: Dovkillia-K [in Ukrainian].

Sergeeva, Yu.M. (2009). Vnutrennyaya rech kak osobaya forma yazyikovogo obscheniya : na materiale angloyazyichnoy hudozhestvennoy literaturyi [Inner speech as a special form of linguistic communication: based on the material of English fiction]. Extended abstract of Candidate's thesis. Moscow [in Russian].

Sokolov, A.N. (1968). Vnutrennyaya rech $i$ myshlenie [Internal speech and thinking]. Moscow: Prosveshchenie [in Russian].

Kholod, O. (2019). Zavdannia psykholinhvistychnoi metodolohii doslidzhen i kvantovyi pidkhid [Tasks of psycholinguistic methodology of research and 
quantum approach]. Psikholingvistika - Psycholinguistics, 25 (2), 338-370. https://doi.org/10.31470/2309-1797-2019-25-2-338-370 [in Ukrainian].

Shytyk, L. (2014). Synkhronna perekhidnist syntaksychnykh odynyts v ukrainskii literaturnii movi [Synchronous transitivity of syntactic units in the Ukrainian literary language]. Cherkasy: vydavets Chabanenko Yu.A. [in Ukrainian].

Shytyk, L.V. (2010). Synkretyzm sposobiv peredavannia vnutrishnoho movlennia [Syncretism of the modes of transmission of inner speech]. Visnyk Cherkaskoho universytetu - Bulletin of Cherkasy University, 193, 12-22 [in Ukrainian].

Shytyk, L.V. (2017). Synkretyzm sposobiv peredavannya chuzhoyi movy v idiostyli Stepana Procyuka [Syncretism of the ways of transferring another's speech in the idiostyle of Stepan Protsyuk]. Movoznavchyj visnyk - Linguistics Bulletin, 22-23, 15-23 [in Ukrainian].

Shlegel, F. (1983). Estetika. Filosofiya. Kritika [Aesthetics. Philosophy. Criticism] (Yu.N. Popova, Trans.). (Vols. 2). Moscow: Iskusstvo [in Russian].

Shulzhuk, N. (2001). Syntaksychni osoblyvosti konstruktsii z chuzhoiu movoiu u dialozi [Syntactic features of constructions with another's speech in a dialog]. Linhvistychni studii - Linguistic studios, 8, 109-112) [in Ukrainian].

Ehrich, J.F. (2006). Vygotskyan inner speech and the reading process. Australian Journal of Educational and Developmental Psychology, 6, 12-25.

Hermans, H.J.M. (2003). The construction and reconstruction of a dialogical self. Journal of Constructivist Psychology, 16, 89-130. https://doi. org/10.1080/10720530390117902

Hickok, G. (2001). Functional Anatomy of Speech Perception and Speech Production: Psycholinguistic Implications. Journal of Psycholinguistic Research, 30, 225-235. https://doi.org/10.1023/A:1010486816667

Puchalska-Wasyl, M. (2006). Nasze wewnętrzne dialogi. O dialogowości jako sposobie funkcjonowania człowieka. Wrocław: Wydawnictwo Uniwersytetu Wrocławskiego [in Polish].

\section{АНОТАЦІЯ}

Мета дослідження. Комплексно проаналізувати способи передавання внутрішнього мовлення персонажів у психолінгвістичній проекції.

Методи та методики дослідження. Під час дослідження використано загальнонаукові методи (аналізу, синтезу, спостереження, опису, класифікації, дефрініційного аналізу) та лінгвістичні й психолінгвістичні методи (структурний, представлений методиками структурно-семантичного, компонентного та опозиційного аналізу, метод діалогічної інтерпретації тексту). Матеріалом слугувала "психобіографічна трилогія" Степана Процюка про українських письменників - Василя Стефраника («Троянда ритуального болю»), Архипа Тесленка («Чорне яблуко») та Володимира Винниченка («Маски опадають повільно»).

Результати. 3'ясовано змістову багатозначність і галузеву полівекторність поняття «внутрішнє мовлення» з позицій психології, психолінгвістики, фрілософії, літературознавства та лінгвістики. Інтегрований підхід до розуміння суті внутрішнього мовлення грунтований на його діалогічності, віртуальній комунікативності й автокомунікативності, взаємозалежності 
мови і мовлення. Окреслено кваліфікаційні характеристики внутрішньої прямої мови та невласне-прямої мови, описано їхні структурно-семантичні різновиди. Внутрішня пряма мова постає не тільки для відтворення монологічних роздумів героїв, але і як форма внутрішньої, завуальованої розмови їх між собою. з огляду на це виокремлено дві форми представлення внутрішньої прямої мови: монологічну і діалогічну. Невласне-пряму мову диференційовано на два різновиди залежно від стилістичних орієнтирів та ступеня наближення до прямої мови: "літературну» («авторську») і "характерологічну» («персональну»). 3’ясовано функційно-стилістичний потенціал способів передавання внутрішнього мовлення в ідіостилі Степана Процюка.

Висновки. Широковживані в психобіографічних романах Степана Процюка способи відтворення внутрішнього мовлення - внутрішня пряма мова й невласне-пряма мова - дають додатковий лінгвостилістичний матеріал для створення психологічних портретів героїв, сприяють художньому розв'язанню проблеми напруженості між мовою автора й мовою героя, допомагають налагодити взаємопереходи в їхньому діалозі, скорочують дистанцію між оповідачем і героєм, героєм і читачем.

Ключові слова: внутрішне мовлення, внутрішній монолог, внутрішня пряма мова, невласне-пряма мова, чужа мова, синкретичні способи передавання чужої мови.

\section{Шитик Людмила \& Акимова Алина. Способы передачи внутренней речи персонажей: психолингвистическая проекция}

\section{АННОТАЦИЯ}

Цель исследования. Комплексно проанализировать способы передачи внутренней речи персонажей - внутренней прямой речи и несобственнопрямой речи - в психолингвистической проекции.

Методы и методики исследования. В ходе исследования использованы общенаучные методы (анализа, синтеза, наблюдения, описания, классификации, дефиницийного анализа), лингвистические и психолингвистические методы (представленные методиками структурно-семантического, компонентного и оппозиционного анализа, метод диалогической интерпретации текста). Материалом послужила "психобиографическая трилогия» Степана Процюка об украинских писателях - Василии Стефанике («Роза ритуальной боли»), Архипе Тесленко ("Черное яблоко») и Владимире Винниченко («Маски опадают медленно»).

Результаты. Выяснена смысловая многозначность и отраслевая поливекторность понятия «внутренняя речь» $c$ позиций психологии, психолингвистики, философии, литературоведения и лингвистики. Интегрированный подход $к$ пониманию сущности внутренней речи основанный на его диалогичности, виртуальной коммуникативности и автокомуникативности, взаимозависимости языка и речи. Определены квалификационные характеристики внутренней прямой речи и несобственно- 
Способи передавання внутрішнього мовлення персонажів...

прямой речи, описаны их структурно-семантические разновидности. Внутренняя речь не только воспроизводит монологические размышления героев, но и является формой внутреннего, завуалированного разговора их между собой. Учитывая это, выделены две фрормы передачи внутренней прямой речи: монологическая и диалогическая. Несобственно-прямая речь дифреренцирована на две разновидности в зависимости от стилистических ориентиров и степени сходства с прямой речью: "литературная» («авторская») и "характерологическая» («персональная»). Установлен функционально-стилистический потенциал способов передачи внутренней речи в идиостиле Степана Процюка.

Выводы. Используемые в психобиографических романах Степана Прочюка способы передачи внутренней речи (внутренняя прямая речь и несобственнопрямая речь) являются дополнительным лингвостилистическим материалом для создания психологических портретов героев. Они способствуют художественному решению проблемы напряженности между речью автора и речью героя, помогают наладить взаимопереходы в их диалоге, сокращают дистанцию между рассказчиком и героем, героем и читателем.

Ключевые слова: внутренняя речь, внутренний монолог, внутренняя прямая речь, несобственно-прямая речь, чужая речь, синкретические способы передачи чужой речи. 